\title{
Konsentrasi C-organik dan substrat sedimen di perairan Pelabuhan Belawan Medan
}

\author{
Y. Yolanda ${ }^{1 *}$, H. Effendi ${ }^{2}$, B. Sartono ${ }^{3}$ \\ 1Program Studi Pengelolaan Sumberdaya Alam dan Lingkungan, Institut Pertanian Bogor, Bogor, \\ Indonesia \\ 2Pusat Penelitian Lingkungan Hidup, Institut Pertanian Bogor, Bogor, Indonesia \\ ${ }^{3}$ Departemen Statistika, Institut Pertanian Bogor, Bogor, Indonesia
}

\begin{abstract}
Abstrak.
Penelitian ini bertujuan mengetahui konsentrasi Corganik dan substrat pada sedimen di perairan Pelabuhan Belawan, serta melihat korelasi antar keduanya. Lokasi penelitian dilakukan di DLKr dan DLKp Pelabuhan Belawan Medan dengan pengambilan sampel secara random sampling sebanyak 10 sampel. Analisis data menggunakan analisis korelasi Pearson product moment. Hasil penelitian menunjukkan konsentrasi Corganik berkisar 0,26-2,74\%. Konsentrasi substrat pasir 61-99\%, lumpur 1-29\%, dan liat 0-18\%. C-organik memiliki korelasi positif terhadap nilai interpretasi substrat lumpur $(0,769)$, namun berkorelasi negatif terhadap substrat pasir $(-0,816)$. Semakin halus substrat sedimen, kandungan C-organik akan semakin meningkat.

Kata Kunci: C-organik, pelabuhan, sedimen
\end{abstract}

\begin{abstract}
The study aims to determine the concentration of organic carbon and substrate in waters sediments of the Belawan Harbour and see correlation with each other. The location of the study was conducted in DLKr and DLKp in Belawan Port, Medan. Sampling method used random sampling with 10 samples. Data analysis using Pearson product moment correlation analysis. The results of the analysis of organic $C$ concentrations ranged from 0.26 to $2.74 \%$, while for the concentration of each substrate were 61 -99\% sand, 1 $29 \%$ sludge, and 0 - 18\% clay. The analysis shows that organic $C$ has a positive correlation with the value of the interpretation of the mud substrate (0.769) while the sand substrate has a negative correlation (-0.816). The finer the sediment substrate, the higher the $C$-organic content in aquatic sediments.
\end{abstract}

Keywords: C-organic, harbour, sediment

\section{PENDAHULUAN}

Pelabuhan Belawan merupakan pelabuhan terbesar ketiga di Indonesia setelah Pelabuhan Tanjung Priok dan Tanjung Perak. Posisi geografis pelabuhan Belawan terletak berhadapan dengan selat Malaka, sehingga memiliki potensi yang tinggi sebagai pusat pengoperasian dan pengembangan ekonomi daerah. Pelabuhan ini terletak di muara dua buah sungai besar yang ada di Kota Medan yaitu Sungai Belawan dan Sungai Deli, sehingga muatan yang terbawa dari hulu hingga ke hilir beraneka ragam yang kemudian terendapkan di dasar perairan.

Salah satu tolok ukur kesuburan perairan adalah kandungan bahan organik di dalamnya. Bahan organik dalam jumlah tertentu akan berguna bagi perairan, namun apabila jumlah yang masuk berlebihan, maka akan mengganggu peruntukan perairan. Gangguan yang dimaksud berupa pendangkalan dan penurunan kualitas air (Odum 1997 dalam Sari et al. 2014). Sedimentasi atau pendangkalan di wilayah pelabuhan akan menyebabkan kapal tidak bisa bersandar atau berlayar. Alternatif yang sering dilakukan oleh pihak pelabuhan untuk mengatasi pendangkalan dan mempertahankan kedalaman operasional

\footnotetext{
* Korespondensi Penulis

Email: yolanda_yuni@yahoo.co.id
} 
adalah dengan pengerukan. Namun, pada kenyataannya pengerukan bukan saja menjadi pemecah masalah sedimentasi, bahkan akan meningkatkan kekeruhan yang pada akhirnya menyebabkan penurunan jumlah spesies avertebrata (De Leeuw et al. 2010).

Sedimen yang terkontaminasi akan berdampak pada spesies akuatik, rantai makanan dan akhirnya pada kesehatan manusia Pourabadehei and Mulligan (2016). Dampak sosial ekonomi terhadap para nelayan yang menggantungkan hidupnya pada mencari ikan adalah semakin jauhnya wilayah operasi penangkapan ikan yang berimbas pada peningkatan biaya operasional.

Menurut Killops and Killops (1993), proses sedimentasi terjadi karena adanya pengendapan bahan organik dalam sedimen laut. Namun pada kondisi toksik, jumlah senyawa organik yang terendap di sedimen dapat berkurang akibat keberadaan oksigen di perairan (terjadi oksidasi). Oleh sebab itu, perlu dilakukan penelitian mengenai kandungan bahan organik (khususnya Corganik) dan melihat substrat sedimen di perairan Pelabuhan Belawan, Medan.

\section{METODOLOGI}

\subsection{Lokasi kajian dan waktu penelitian}

Pengambilan sampel sedimen dilakukan pada bulan Desember 2018 di perairan Daerah Lingkungan Kerja (DLKr) dan Daerah Lingkungan Kepentingan (DLKp) Pelabuhan Belawan Medan, yang meliputi Muara Sungai Belawan dan Sungai Deli (sebelum \& setelah adanya aktivitas pelabuhan). Titik pengambilan sampel berjumlah 10 stasiun (Gambar 1 dan Tabel 1). Analisis sampel sedimen dilakukan di Laboratorium Pusat Penelitian Kelapa Sawit (PPKS) Medan. Analisis data menggunakan analisis korelasi Pearson product moment.

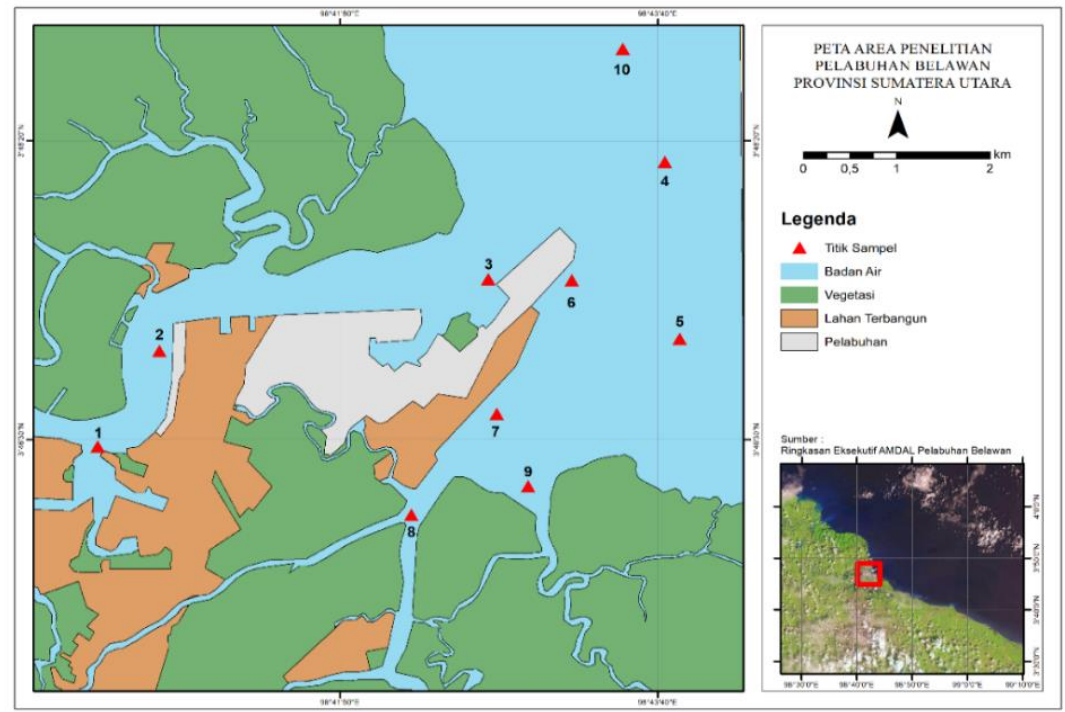

Gambar 1. Lokasi penelitian di perairan Pelabuhan Belawan. 
Tabel 1. Lokasi pengamatan parameter sedimen perairan.

\begin{tabular}{clcc}
\hline Kode & \multirow{2}{*}{ Titik Pengambilan Sampel Sedimen } & \multicolumn{2}{c}{ Koordinat } \\
\cline { 3 - 4 } Stasiun & & Lintang & Bujur \\
\hline ST1 & Muara Sungai Belawan & $3^{\circ} 46^{\prime} 27,39^{\prime \prime} \mathrm{LU}$ & $98^{\circ} 40^{\prime} 26,15^{\prime \prime} \mathrm{BT}$ \\
ST2 & Terminal Penumpang-LANTAMAL & $3^{\circ} 47^{\prime} 02,63^{\prime \prime} \mathrm{LU}$ & $98^{\circ} 40^{\prime} 47,55 " \mathrm{BT}$ \\
ST3 & Dermaga bongkar muat & $3^{\circ} 47^{\prime} 29,11^{\prime \prime} \mathrm{LU}$ & $98^{\circ} 42^{\prime} 41,42^{\prime \prime} \mathrm{BT}$ \\
ST4 & Proyek Reklamasi (pembangunan) & $3^{\circ} 48^{\prime} 12,20^{\prime \prime} \mathrm{LU}$ & $98^{\circ} 43^{\prime} 42,50 " \mathrm{BT}$ \\
ST5 & Laut Sungai Deli & $3^{\circ} 47^{\prime} 07,10^{\prime \prime} \mathrm{LU}$ & $98^{\circ} 43^{\prime} 47,70^{\prime \prime} \mathrm{BT}$ \\
ST6 & Wisata Ocean Pasifik & $3^{\circ} 47^{\prime} 28,60^{\prime \prime} \mathrm{LU}$ & $98^{\circ} 43^{\prime} 10,30^{\prime \prime} \mathrm{BT}$ \\
ST7 & Pelabuhan Perikanan Belawan (PPS) & $3^{\circ} 46^{\prime} 39,40^{\prime \prime} \mathrm{LU}$ & $98^{\circ} 42^{\prime} 44,30 " \mathrm{BT}$ \\
ST8 & Muara Sungai Deli I & $3^{\circ} 46^{\prime} 02,28^{\prime \prime} \mathrm{LU}$ & $98^{\circ} 42^{\prime} 14,77^{\prime \prime} \mathrm{BT}$ \\
ST9 & Muara Sungai Deli II & $3^{\circ} 46^{\prime} 12,70^{\prime \prime} \mathrm{LU}$ & $98^{\circ} 42^{\prime} 55,20 " \mathrm{BT}$ \\
ST10 & Laut Sungai Belawan & $3^{\circ} 48^{\prime} 53,90^{\prime \prime} \mathrm{LU}$ & $98^{\circ} 43^{\prime} 27,90^{\prime \prime} \mathrm{BT}$ \\
\hline
\end{tabular}

\subsection{Analisis data}

Data primer dianalisis dan diolah dalam bentuk tabel dan grafik melalui aplikasi Microsoft Excel 2016. Korelasi antar variabel dianalisis dengan metode korelasi Pearson Product Moment yang kemudian diinterpretasikan secara rinci dan dilakukan perhitungan korelasi secara keseluruhan menggunakan software SPSS 16.0. Tahapan-tahapannya adalah sebagai berikut :

1) Interpretasi harga $r$

- Nilai $r$ terbesar adalah +1 dan terkecil adalah $-1(r=+1$ menunjukkan hubungan positif sempurna, $r=-1$ menunjukkan negatif sempurna).

- $r$ tidak mempunyai satuan atau dimensi. Tanda + atau - hanya menunjukkan arah hubungan. Interpretasi terhadap koefisien korelasi secara konvensional disajikan pada Tabel 2 (Guilford 1956).

Tabel 2. Pedoman derajat hubungan.

\begin{tabular}{cc}
\hline Koefisien Korelasi r & Interpretasi \\
\hline $0,80-1,00$ & Sangat tinggi \\
$0,60-0,80$ & Tinggi \\
$0,40-0,60$ & Cukup \\
$0,20-0,40$ & Rendah \\
$0,00-0,20$ & Sangat rendah \\
\hline
\end{tabular}

2) Pengambilan keputusan menggunakan derajat signifikansi sebagai berikut:

- Jika nilai signifikansi $<0,05$, maka berkorelasi.

- Jika nilai signifikansi >0,05, maka tidak berkorelasi.

3) Perhitungan korelasi keseluruhan menggunakan SPSS 16.0.

\section{HASIL DAN PEMBAHASAN}

\subsection{Kandungan C-organik pada sedimen perairan Pelabuhan Belawan}

Karbon organik (C-organik) merupakan salah satu komponen penting sebagai penyusun kimiawi sedimen. Meskipun komponen organik dapat 
terdekomposisi dan dikembalikan sebagian ke komponen anorganik, sebagiannya lagi masih terpreservasi dan menjadi komponen penting sebagai bagian dari penyusunan partikel sedimen di perairan. Hasil pengamatan kandungan C-organik pada setiap stasiun berbeda-beda. Kandungan C-organik di perairan Pelabuhan Belawan bervariasi berkisar 0,26-2,74\% (Tabel 3).

Tabel 3. Konsentrasi C-organik sedimen perairan Pelabuhan Belawan.

\begin{tabular}{cc}
\hline Stasiun & Konsentrasi C-organik (\%) \\
\hline ST1 & 2,10 \\
ST2 & 2,74 \\
ST3 & 1,42 \\
ST4 & 0,26 \\
ST5 & 0,76 \\
ST6 & 2,09 \\
ST7 & 1,89 \\
ST8 & 2,65 \\
ST9 & 1,96 \\
ST10 & 1,54 \\
\hline
\end{tabular}

Kandungan C-organik dalam sedimen menunjukkan hasil tertinggi di stasiun 8 (Muara Sungai Deli I) sebesar 2,65 \% dan yang terendah di stasiun 4 (kawasan pembangunan reklamasi) sebesar 0,26\% (Gambar 2). Hal ini disebabkan, stasiun 8 merupakan Muara Sungai Deli karena di sepanjang aliran sungai banyak ditemukan tumbuhan yang diduga dapat menambah konsentrasi C-organik. Hasil dari pelapukan dedaunan yang berjatuhan di sekitar aliran sungai akan terbawa sampai muara sungai serta organisme berasosiasi dengannya kemudian mati dan terdegradasi dalam endapan (Habibi et al. 2014). Mikroba mentransfer substrat ke dalam sel melalui membran sitoplasma untuk melakukan proses dekomposisi bahan organik sehingga terjadi proses mineralisasi sedimen (Kristensen et al. 2008). Selain itu terdapat mangrove di sekitarnya yang diduga berpengaruh pada konsentrasi bahan organik, karena mangrove mampu menangkap bahan organik yang masuk ke muara sungai.

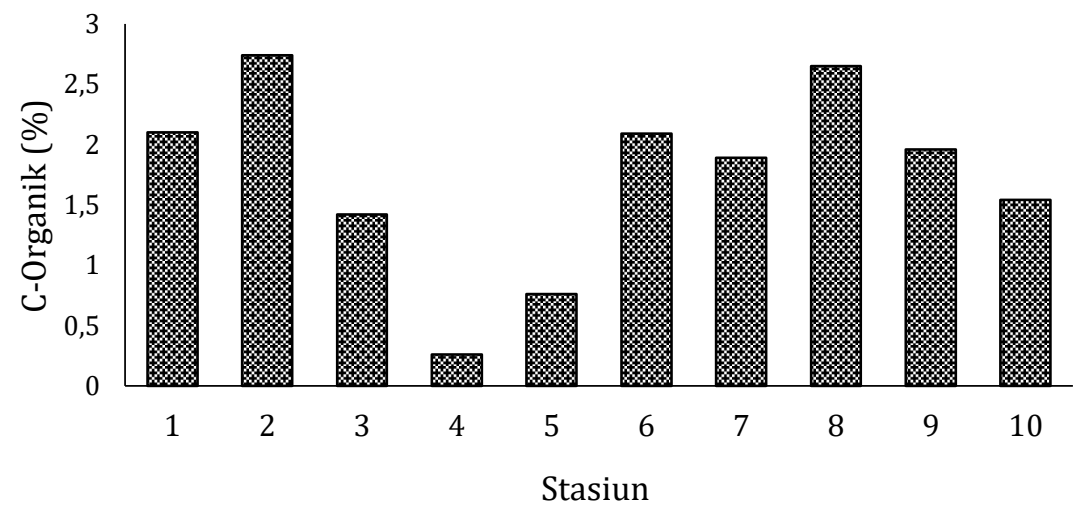

Gambar 2. Kandungan C-organik sedimen perairan Pelabuhan Belawan. 


\subsection{Kandungan substrat sedimen perairan Pelabuhan Belawan, Medan}

Substrat pada sedimen merupakan parameter yang sangat penting bagi biota yang hidup di dasar perairan, misalnya siput gonggong yang menjadikan sedimen sebagai tempat hidup (habitat), memijah, bereproduksi, dan mencari makan. Hal ini erat kaitannya dengan aktivitas siput gonggong yang banyak berhubungan dan dipengaruhi oleh kandungan dasar perairan itu sendiri.

Tipologi substrat di perairan Pelabuhan Belawan Medan pada umumnya terdiri dari tiga segmen yaitu pasir, lumpur dan liat dengan komposisi pasir lebih tinggi pada setiap stasiunnya (Tabel 4). Kandungan substrat pada setiap stasiun berbeda pada masing-masing segmen. Hal ini dikarenakan pada setiap stasiun memiliki karakteristik dan kegiatan antropogenik yang berbeda-beda pula.

Tabel 4. Konsentrasi substrat sedimen perairan Pelabuhan Belawan.

\begin{tabular}{cccc}
\hline Stasiun & Pasir $(\%)$ & Lumpur $(\%)$ & Liat (\%) \\
\hline ST1 & 67 & 15 & 18 \\
ST2 & 69 & 17 & 14 \\
ST3 & 67 & 19 & 14 \\
ST4 & 99 & 1 & 0 \\
ST5 & 79 & 9 & 12 \\
ST6 & 61 & 29 & 10 \\
ST7 & 69 & 19 & 12 \\
ST8 & 61 & 23 & 16 \\
ST9 & 77 & 15 & 8 \\
ST10 & 73 & 17 & 10 \\
\hline
\end{tabular}

Persentase tertinggi pada segmen substrat pasir ditemukan di stasiun 4 (kawasan reklamasi) yakni sebesar $99 \%$, sedangkan yang terendah ditemukan pada stasiun 6 (Ocean Pasifik) dan 8 (Muara Sungai Deli I). Hal ini diduga karena adanya proyek reklamasi yang saat ini diwajibkan menggunakan pasir laut guna keberlangsungan ekosistem lingkungan, sehingga stasiun 4 memiliki kandungan pasir yang jauh lebih tinggi. Menurut Xin et al. (2017), proyek reklamasi dapat mengubah transportasi sedimen dan siklus air. Perubahan transportasi terjadi pada lapisan bawah pembentukan pulau baru (reklamasi) yaitu pasir, kemudian di lapisan permukaan adalah tanah datar yang dapat menyebabkan subsidensi.

Substrat berlumpur tertinggi terdapat pada stasiun 6 (Ocean Pasifik) sebesar 29\% dan terendah pada stasiun 4 (kawasan reklamasi) sebesar 1\%. Hal ini diduga karena Ocean Pasifik merupakan salah satu kawasan wisata (restoran, kolam pemancingan ikan, area bermain, dsb), sehingga menyebabkan semakin melimpahnya sampah organik seperti sisa buangan makanan pengunjung, kotoran atau air buangan kolam pancingan, dan dedaunan pohon yang jatuh ke perairan. Hal ini membuat semakin kompleksnya masukan sampah organik yang kemudian mengendap di dalam sedimen. 
Kandungan C-organik pada substrat liat ditemukan tertinggi pada stasiun 1 (Muara Sungai Belawan) sebesar 18\% dan terendah pada stasiun 4 (kawasan reklamasi) sebesar 0\% (Gambar 3).

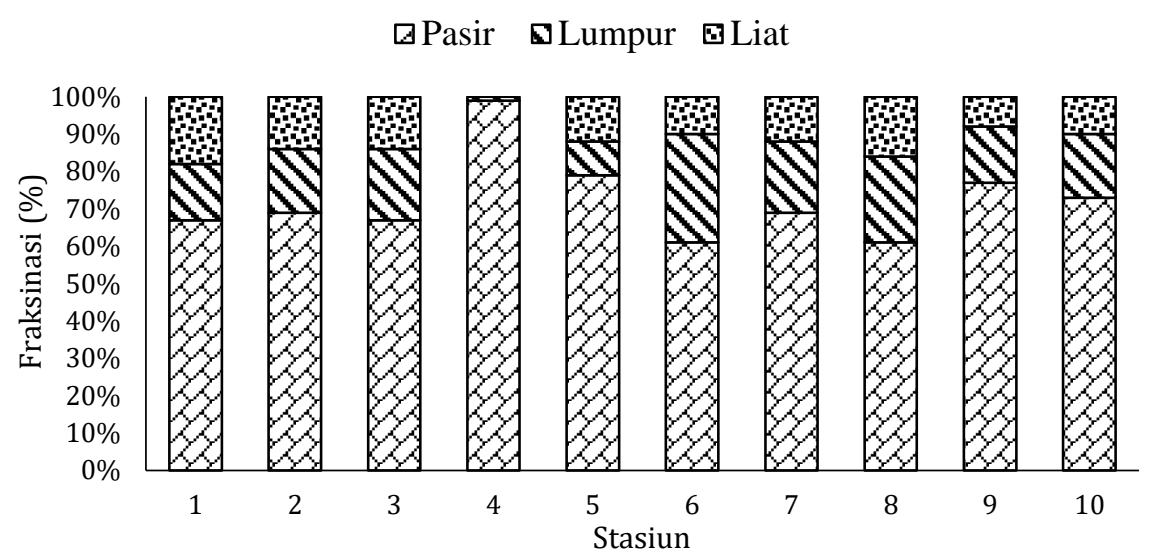

Gambar 3. Kandungan substrat sedimen perairan Pelabuhan Belawan.

\subsection{Korelasi antara C-organik dengan substrat sedimen perairan}

Koefisien interpretasi digunakan untuk menafsirkan skor korelasi Pearson (r) antara C-organik dengan substrat sedimen, begitu juga antar fraksinasi sedimen perairan. Skor korelasi Pearson tersebut dapat dilihat pada Tabel 5.

Tabel 5. Korelasi Pearson antar variabel.

\begin{tabular}{|c|c|c|c|c|c|}
\hline & & C-organik & Pasir & Lumpur & Liat \\
\hline \multirow[t]{3}{*}{ C-organik } & Pearson Correlation & 1 & & & \\
\hline & Sig. (2-tailed) & & & & \\
\hline & $\mathrm{N}$ & 10 & & & \\
\hline \multirow[t]{3}{*}{ Pasir } & Pearson Correlation & $-0,816^{* *}$ & 1 & & \\
\hline & Sig. (2-tailed) & 0,004 & & & \\
\hline & $\mathrm{N}$ & 10 & 10 & & \\
\hline \multirow[t]{3}{*}{ Lumpur } & Pearson Correlation & $0,769^{* *}$ & $-0,928^{* *}$ & 1 & \\
\hline & Sig. (2-tailed) & 0,009 & 0,000 & & \\
\hline & $\mathrm{N}$ & 10 & 10 & 10 & \\
\hline \multirow[t]{3}{*}{ Liat } & Pearson Correlation & $0,654^{*}$ & $-0,826^{* *}$ & 0,556 & 1 \\
\hline & Sig. (2-tailed) & 0,040 & 0,003 & 0,095 & \\
\hline & $\mathrm{N}$ & 10 & 10 & 10 & 10 \\
\hline
\end{tabular}

**. Correlation is significant at the 0.01 level (2-tailed).

*. Correlation is significant at the 0.05 level (2-tailed).

Pada Tabel 5 terlihat bahwa korelasi positif tertinggi didapat antara Corganik dengan lumpur $(0,769)$ (derajat hubungan tinggi). Sebaliknya, nilai korelasi negatif tertinggi didapat antara $\mathrm{C}$-organik dengan pasir $(-0,816)$ (derajat 
hubungan sangat tinggi). Hal ini menunjukkan bahwa semakin tinggi kadar lumpur atau liat yang terkandung pada sedimen, maka semakin tinggi kandungan C-organik yang ada di dalamnya. Berbanding terbalik pada substrat pasir, semakin tinggi kandungan pasir pada sedimen, maka semakin berkurang kandungan C-organiknya. Hal ini karena substrat berpasir tidak memiliki poripori yang rapat, sehingga substrat tidak mampu menyerap C-organik yang kemudian mudah terbawa arus. Substrat lumpur dan liat memiliki pori-pori yang lebih kecil, sehingga C-organik lebih mudah terendapkan. EPA (1985) dalam Hanifah (2007) menyatakan bahwa kandungan bahan organik dalam sedimen sangat berhubungan dengan jenis substratnya, substrat yang berbeda mempunyai kandungan bahan organik yang berbeda pula.

Korelasi diantara jenis substrat menunjukkan nilai tertinggi antara pasir dengan lumpur yang hampir mendekati korelasi sempurna $(1,00)$ yakni $-0,928$ atau sangat tinggi. Hal ini menandakan bahwa, jika suatu perairan banyak mengandung substrat lumpur, maka kandungan substrat pasir berkurang.

Taraf signifikansi $p<0,05$ ditemukan antara jenis substrat pasir dengan lumpur $(0,00)$, pasir dengan liat $(0,003)$ dan pasir dengan C-organik $(0,009)$. Hal ini menunjukkan adanya korelasi (hubungan) pada masing-masing variabel tersebut. Variabel yang tidak memiliki korelasi $(p>0,05)$ adalah antara lumpur dengan liat $(0,095)$ yang juga memiliki hasil interpretasi terkecil $(0,556)$. Grafik korelasi setiap jenis substrat dengan C-organik tersaji pada Gambar 4.
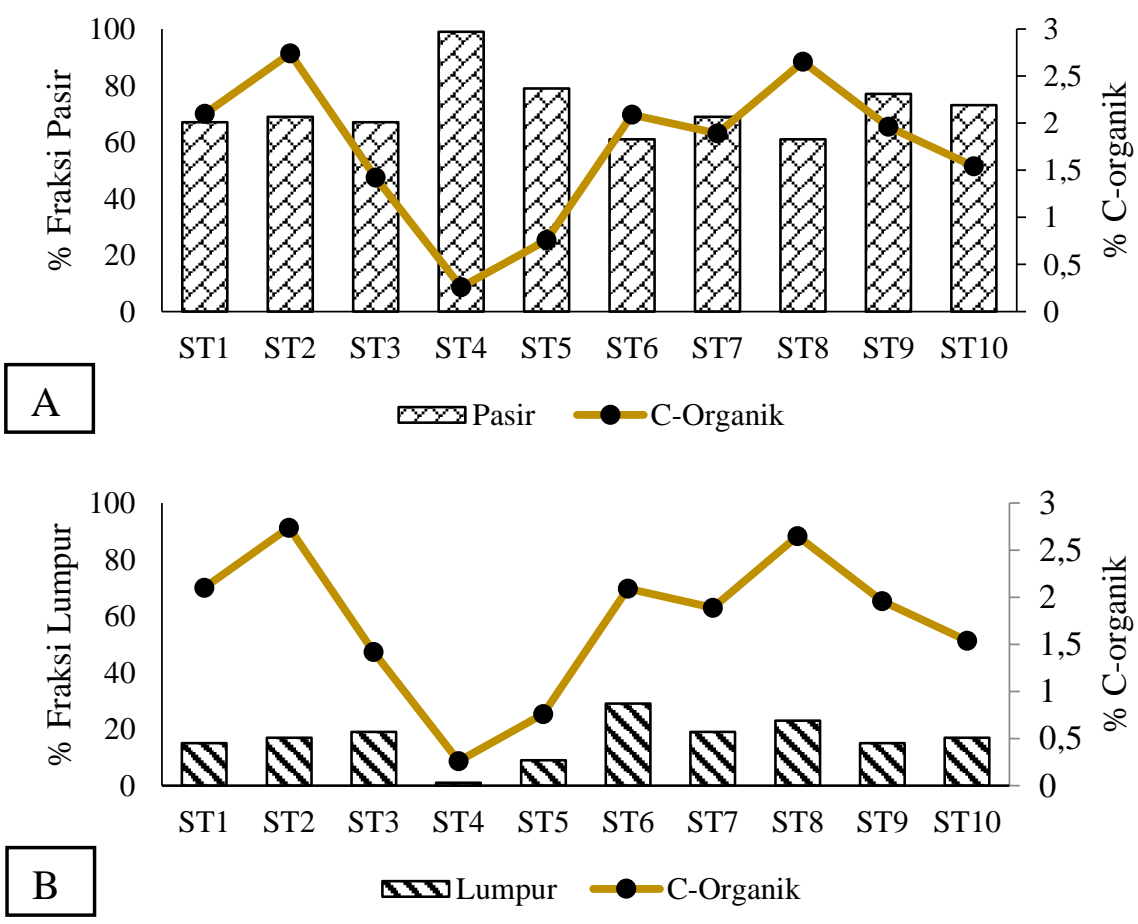


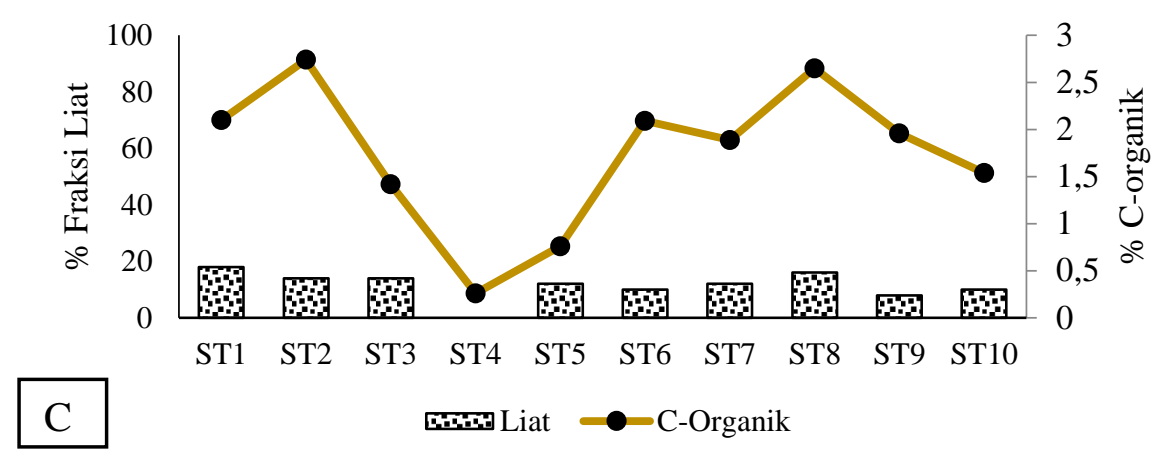

Gambar 4. Korelasi C-organik dengan kandungan substrat.

A :
B : Grafik korelasi C-organik dengan substrat berpasir
C : Grafik korelasi C-organik dengan substrat berlumpur

Kandungan C-organik dengan substrat dalam sedimen menunjukkan adanya korelasi yang kuat satu sama lain. Berdasarkan Gambar 4A, persentase substrat pasir tertinggi terdapat pada stasiun 4 (99\%), sedangkan kandungan Corganiknya di lokasi tersebut merupakan yang terendah (0,26\%). Gambar 4B menunjukkan substrat lumpur tertinggi pada stasiun 6 sebesar 29\%, sedangkan kandungan C-organiknya cukup besar meskipun bukan yang paling besar yaitu 2,09\%. Gambar 4C menunjukkan bahwa semakin halus substrat sedimen, maka jumlah C-organik dalam sedimen semakin besar. Terbukti dengan persentase substrat liat tertinggi terdapat pada stasiun $1(18 \%)$ dan stasiun $8(16 \%)$ yang juga memiliki kandungan C-organik tinggi yakni sebesar 2,10\% dan 2,65\%.

Lokasi stasiun 1 (Muara Sungai Belawan) dan stasiun 8 (muara Sungai Deli) diduga mendapat banyak masukkan bahan organik akibat adanya aktivitas antropogenik dari hulu yang terbawa hingga ke muara sungai. Frohne et al. (2014) melaporkan bahwa sedimen mampu mengakumulasi bahan organik dan logam berat yang berasal dari kegiatan pabrik industri, erosi tanah, pembuangan air limbah, limpasan permukaan di kawasan perkotaan dan industri, serta presipitasi atmosfer yang masuk ke kolom air.

\section{KESIMPULAN DAN SARAN}

Segmen substrat sedimen di perairan Pelabuhan Belawan Medan terdiri dari substrat pasir, lumpur dan liat, yang mana substrat berpasir paling mendominasi di perairan ini. Korelasi antara C-organik dengan substrat sedimen memiliki keterkaitan yang tinggi dengan nilai signifikansi untuk pasir $(0,004)$, lumpur $(0,009)$ dan liat $(0,040)$. C-organik memiliki korelasi positif dengan substrat lumpur $(0,769)$, sedangkan dengan substrat pasir memiliki korelasi negatif $(-0,816)$. Semakin halus substrat sedimen perairan, semakin meningkat pula kandungan C-organik di sedimen perairan tersebut. 


\section{UCAPAN TERIMA KASIH}

Ucapan terima kasih kepada pihak Pelindo I Cabang Belawan Medan yang telah memberikan izin dan banyak membantu dalam proses penelitian ini. Penulis juga mengucapkan terima kasih kepada kedua pembimbing serta kepada semua penulis buku maupun jurnal yang dijadikan sebagai sumber telaah pustaka.

\section{DAFTAR PUSTAKA}

De Leeuw J, Shankman D, Wu G, De Boer WF, Burnham J, He Q and Xiao J. 2010. Strategic assessment of the magnitude and impacts of sand mining in Poyang Lake, China. Reg. Environ. Change 10(2):95-102.

Frohne T, Rinklebe J and Diaz-Bone RA. 2014. Contamination of floodplain soils along the Wupper River, Germany, with $\mathrm{As}, \mathrm{Co}, \mathrm{Cu}, \mathrm{Ni}, \mathrm{Sb}$, and $\mathrm{Zn}$ and the impact of pre-definite redox variations on the mobility of these elements. Soil Sediment Contam. 23:779-799

Guilford JP. 1956. Fundamental statistic in psychology and education. 3rd. Ed. McGraw-Hill Book Company, Inc. New York.

Habibi MA, Maslukah L dan Wulandari SY. 2014. Studi konsentrasi fosfat bioavailable dan karbon organik total (KOT) dalam sedimen di Perairan Benteng Portugis, Jepara. Jurnal Oseanografi 3(4):690-697.

Hanifah MZN. 2007. Kualitas fisika-kimia sedimen serta hubungannya terhadap struktur komunitas makrozoobenthos di Estuari Percut Sei Tuan Kabupaten Deli Serdang [Tesis]. Sekolah Pascasarjana, Institut Pertanian Bogor. Bogor.

Killops SD and Killops VJ. 1993. An introduction to organic geochemistry. Longman Scientific \& Tecnical. London.

Kristensen E, Bouillon S, Dittmar T and Marchand C. 2008. Organic carbon dynamics in mangrove ecosystems: a review. Aquat. Bot 2:201-219.

Pourabadehei M and Mulligan CN. 2016. Resuspension of sediment, a new approach for remediation of contaminated sediment. Environ. Pollut 213:63-75.

Sari TA, Warsito A, dan Rina Z. 2014. Studi bahan organik total (BOT) sedimen dasar laut di Perairan Nabire, Teluk Cendrawasih, Papua. Jurnal Oseanografi 3(1):81-86.

Xin C, Zhu W, Li M, Tian A, Guo J and Gu X. 2017. Research on the influnce of reclamation on water and sediment environment offshore. Journal of Water Resources and Ocean Science 6(4):55-60. 